\title{
Dannelse til globalt medborgerskap. Solidaritetsarbeid i en barnehagekontekst
}

Av Linnéa K. Jermstad, førstelektor, NLA Høgskolen, Per Ivar Kjærgård, førstelektor, NLA Høgskolen og Hilde Sundnes, høgskolelærer, NLA Høgskolen.

\section{Abstrakt}

I rammeplanen for barnehagen kan vi lese at barn skal få mulighet til å utvikle evnen til å vise solidaritet ved å handle lokalt, nasjonalt og globalt. Tidligere forskning viser at solidaritetsarbeid i barnehager gir positive og negative assosiasjoner. Noen av de negative er at tanken om «vi i vesten» og «de andre» forsterkes, og at «de andre» tolkes som et eksotisk fremmedelement. Denne studien undersøker om solidaritetsarbeid i barnehagen kan være fruktbart i en dannelsesprosess mot globalt medborgerskap der holdninger, menneskerettigheter og verdier står sentralt. Studien ble gjennomført i én utvalgt barnehage på Vestlandet som har lang og omfattende erfaring med solidaritetsarbeid. Det empiriske materialet for studien ble innhentet gjennom kvalitativ metodetriangulering bestående av to semistrukturerte gruppeintervjuer med åtte foresatte, semistrukturert intervju med styrer av barnehagen og en analyse av barnehagens plandokument for solidaritetsprosjektet. Resultatene viser styrker og svakheter ved solidaritetsarbeid i barnehagen, og trekker frem flere elementer som kontinuitet, filosofiske samtaler og en betydningsfull rollefigur som viktige faktorer for at solidaritetsarbeid kan bidra til å danne barn mot globalt medborgerskap.

Nøkkelord: Globalt medborgerskap, solidaritet, filosofiske samtaler, danning, barnehagen 


\section{Abstract}

The framework for kindergartens in Norway sets out that children should be given the opportunity to show solidarity by acting locally, nationally and globally. Previous research shows that solidarity work in kindergartens has positive and negative associations. Some of the negative include that the idea of «us in the West» versus "the others» is reinforced and that «the others» is interpreted as an exotic foreign element. This study examines whether solidarity work in kindergarten can be fruitful in an educational process working towards global citizenship where attitudes, human rights and values are central. The study was conducted in a pre-selected kindergarten in western Norway that has long and extensive experience with solidarity work. The empirical material was obtained through qualitative method triangulation. This consisted of two semi-structured group interviews with eight parents, a semi-structured interview with the kindergarten's management and an analysis of the solidarity project's plan document used by the kindergarten. The results display the strengths and weaknesses of solidarity work in the kindergarten, and highlight several elements such as continuity, philosophical conversations and an important role figure as crucial factors for solidarity work to help educate children towards global citizenship.

Keywords: global citizenship, solidarity, philosophical discussions, kindergarten

\section{Introduksjon}

Begrepet "globalt medborgerskap» finner vi aktualisert i Incheon-deklarasjonen «Utdanning 2030» (UNESCO, 2015) der det ble satt globale og nasjonale mål for utfordringer innen utdanning. Deklarasjonen ble videre konkretisert i Unescos rapport «Global Education Monitoring Report, 2019: Migration, Displacement and Education - Building Bridges, not Walls» (UNESCO, 2019). Utdanning 2030 (UNESCO, 2015) er et rammeverk som viser hvordan UNESCO's mål kan nås. En av målsetningene for utdanning 2030 er at alle barn og unge innen utdanningssektoren skal ha 
kunnskap om og nødvendige ferdigheter for å fremme globalt medborgerskap (UNESCO, 2019, s. 189). Denne målsetningen aktualiseres i Rammeplanen for barnehagen (2017) der barnehager pålegges å legge til rette for at barn lærer om solidaritet, grunnleggende rettigheter og bærekraftig utvikling. Her står solidaritet sentralt i et globalt perspektiv. Barnehagens dannelsesmandat, slik det fremgår av rammeplan for barnehagen, inneholder moralske og rettslige komponenter som bærekraftig utvikling og solidaritet (Kunnskapsdepartementet, 2017). Solidaritet er både et juridisk og et etisk begrep som viser til en moralsk forpliktelse eller det å stå sammen om noe. Solidaritet skal virkeliggjøres i barnehagens hverdag og bli en varig verdi i barnas liv (Thoresen \& Winje, 2017, s. 86).

I barnehagen der denne undersøkelsen fant sted, var det gjort et tiårig arbeid med utgangspunkt i et solidaritetsprosjekt, Stefanusprosjektet, for å fremme verdier som solidaritet og likeverd. Arbeidet er gjort årlig og over flere måneder og ender i en markering av prosjektet på FN-dagen. I denne barnehagen, som i mange barnehager, knyttes FN-dagen til solidaritetsarbeid der intensjonen er innsamling av midler, men også å gi barna et globalt perspektiv på utfordringer i verden. Stefanusprosjektet, ledet av universitetsprofessor Magda Gobran, også kalt «Mamma Maggie», arbeider for å bedre levekårene til barna som vokser opp på søppelhauger i Kairo (Skeie, 2014). Mamma Maggie anses for å være Egypts mor Teresa (The Citizen, 2020, 17.mars). Hun mottok «Secretary of State's International Woman of Courage Award» i 2019 av USAs førstedame Melania Trump og USAs utenriksminister Mike Pompeo for sitt engasjementet for menneskerettigheter, likeverd og fred. Mamma Maggie har også flere ganger vært nominert til «Nobels fredspris» av nasjonale og internasjonale institusjoner for arbeidet med de underpriviligertes rettigheter og utdanning, blant annet i 2012 og i 2020 (The Citizen, 2020, 17.mars).

I barnehagens planer kan vi lese om flere målsetninger med solidaritetsarbeidet som alle på sin måte realiserer sentrale verdier i rammeplan for barnehagen og menneskerettighetene. Solidaritetsarbeidet er ansett som en viktig del av det didaktiske arbeidet for å fremme verdier knyttet til solidaritetsarbeid, respekt for lokalkunnskap og globalt medborgerskap. Globalt medborgerskap gir assosiasjoner til ansvar, likeverd og solidaritet, og beskrives av Hancock på følgende måte; "Global citizens are empowered by a lack of 
physical and virtual boundaries [...] through occupying individual identities, all are members of the same global community» (Hancock, 2017, s. 572). Studien i denne barnehagen favner inn under globalt medborgerskap i den forstand at blikket rettes utover Norges grenser mot barn som lever under andre levekår. Solidaritetsarbeidet bidrar på den måten til en danningsprosess som kan utvide barnas horisont.

Det finnes imidlertid noen fallgruver knyttet til solidaritetsarbeid i barnehagen. Bakken \& Børhaug (2009) og Spernes \& Hatlem (2019) stiller kritiske spørsmål til hvordan menneskene vi skal hjelpe fremstilles for barna. Sageidet (2015) stiller seg kritisk til om avstanden mellom de gode intensjonene og praktisk realisering blir for store. Hun hevder at det trengs mer «forskning og debatt i praksisfeltet» for å realisere intensjoner og målsetninger. (Sageidet, 2015).

I lov om barnehager $\$ 1$ formål kan vi lese at barnehagen skal fremme læring og danning som grunnlag for allsidig utvikling (Barnehageloven, $2005, \$ 1)$. Videre kan vi lese at barn skal få undre seg og oppleve gleden ved å utforske. Undring og utforskning er grunnleggende elementer ved filosofiske samtaler, og i en barnehagekontekst er de fruktbare virkemidler til å undersøke hva som er felles, og hva som er forskjellig (Olsholt \& Schelderup, 2018, s. 152). De er en nødvendig del av barnets dannelse (Olsholt \& Schelderup, 2018, s. 78). Danningsaspektet skal bidra til kritisk refleksjon. «Danning kan forstås som en måte å bli bevisst sine verdier og normer og sin egen førforståelse på i møte med noe nytt som utfordrer det en tidligere tok for gitt» (Bergersen, 2017, s. 27). Dannelsen kan sies å bestå av tre hovedkomponenter; barnets eller menneskets forhold til seg selv, menneskets forhold til verden og menneskets forhold til samfunnet det lever i. Dannelse er en prosess som handler om en åpenhet til å forstå mer eller forstå noe på en annen måte (Bergersen 2017, s. 27).

\section{Forskningsspørsmål}

For å belyse barnehagens solidaritetsarbeid hadde studien som mål å se nærmere på hvordan barnehagen beskriver solidaritetsarbeid i sine planer og foresattes erfaringer med prosjektet. Artikkelens forskningsspørsmål er: 
«Hvordan bidrar barnehagens solidaritetsarbeid til at barn dannes til globalt medborgerskap?»

\section{Metode}

For å undersøke barn og foresattes erfaringer med barnehagens solidaritetsprosjekt ble det valgt en kvalitativ tilnærming som «tar sikte på å fange opp mening og opplevelse som ikke lar seg tallfeste eller måle» (Dalland, 2012, s. 112). Kvalitative metoder fremskaffer en datatype som gir dybdeinformasjon som er relevant for denne artikkelens forskningsfokus og problemstilling. Det empiriske grunnlaget er fremskaffet gjennom litteratursøk, semistrukturert gruppeintervju med foresatte, dybdeintervju med styrer og kvalitativ dokumentanalyse av barnehagens plandokument. Metodetriangulering er valgt for å innhente et større datagrunnlag og for å styrke validiteten i dataene (Krumsvik, 2019, s. 187).

Litteratursøket ble gjort i databasene Idunn, Ebsco, Oria og Google Scholar. Søkeordene var blant annet «solidaritet barnehage», «bistandsarbeid barnehage», "globalt medborgerskap barnehage», "world citizen preschool». Inklusjonskriterier var nordisk/engelsk språk, publiseringsårtsall fra 2015, men grunnet treff måtte vi utvide kriteriet knyttet til publiseringsårstall.

Inklusjonskriterier for gruppeintervjuene var at de hadde hatt flere barn i barnehagen i mer enn 5 år slik at de hadde deltatt i det årlige solidaritetsarbeidet flere ganger. De åtte informantene var sammensatt av begge kjønn, og det er gjennomført to slike intervju med fem foresatte i den første gruppen og tre foresatte i den andre gruppen. Disse informantene blir kalt foresatt 1-5 dag 1 og foresatt 1-3 dag 2. Intervjuets form var semi-strukturert, og beskrives slik: «[...] semi-structured interviewing are used so that the researcher can keep an open mind about the shape of what he or she needs to know about, so that concepts and theories can emerge out of the data.» (Bryman, 2016, s. 10). For å sikre best mulig kvalitet på de empiriske dataene ble gruppeintervjuet tatt opp og transkribert etter godkjenning fra NSD. Dybdeintervjuet ble gjennomført uten opptak, men det ble tatt notater underveis som styrer i etterkant godkjente. 
I den videre analysen av dataene ble det gjort en meningsfortetting av gruppeintervjuene der de ble kategorisert i tre hovedfunn: «Mamma Maggie; en rollefigur for barna», "Kontinuitet er betydningsfullt for holdningsdanning» og «Å tenke globalt og lokalt; å sette ting i perspektiv». Metodelitteraturen beskriver prosessen slik «data analysis in qualitative research consists of preparing and organizing the data [...] for analysis, then reducing the data into themes through a process of coding and condensing the codes [...]» (Creswell, 2013, s. 180). Slik kunne de foresattes refleksjoner samles og rettes inn mot problemstillingen.

Dokumentanalyse ble valgt for å innhente data om formål og didaktiske pedagogiske metoder for gjennomføring av prosjektet. Dokumentene som er analysert er barnehagens virksomhetsplan, barnehagens årsplan og Pedagogisk plandokument for Stefanusprosjektet. Dokumentanalysen har også en kvalitativ tilnærming der vi ser nærmere på egenskapene som vi finner i innholdsanalysen (Krumsvik, 2019, s. 186).

Metodevalget har sine begrensninger da vi ikke kan generalisere basert på våre funn. Målet er likevel at prosjektet skal bidra til å fremskaffe empiri om solidaritetsarbeid i barnehager, og at andre barnehager kan få utbytte av funnene i studiet. Det er flere utfordringer knyttet til å bruke kvalitativ metode og gruppeintervju om et verdiladet tema, foresatte kan i intervjusituasjonen være opptatt av å gi svar som en tror forsker forventer og er sosialt akseptert noe som vil kunne svekke funnenes reliabilitet. Mulige svakheter med dybdeintervjuet kan være at styrer kan gi en tendensiøs fremstilling av prosjektet.

\section{Resultat og diskusjon}

\section{Mamma Maggie, en rollefigur for barna.}

Flere av informantene uttrykte at prosjektets frontfigur Mamma Maggie er viktig for barnas engasjement for og kunnskap om prosjektet. I tillegg til at hun er en drivkraft i prosjektet, kan det synes som at hennes rolle som verdiformidler overfor barna er viktig. Gjennom ord og handlinger formidler hun verdier som er sentrale i menneskerettighetene, som menneskeverd, like- 
verd og toleranse. Dette bekrefter de foresatte når vi spør om prosjektet øver barna i å tenke og handle slik at det tjener en annen: "Ja, det øver dem [...] Mamma Maggie, det at én person kan gjøre en stor forskjell» (foresatt 1, dag 2). Inntrykket forsterkes ytterligere når en annen informant reflekterer rundt det som har gjort mest inntrykk på barnet deres: «Altså hun som person føler jeg har gjort inntrykk på dem [...] det at hun bruker hele livet sitt for å hjelpe de barna. Det føler jeg er noe som sitter igjen hos dem» (foresatt 1, dag 1). Ser vi disse funnene i lys av aktuelle mål i rammeplan for barnehagen kan det synes som at et prosjekt med en så tydelig verdiformidler som mamma Maggie bidrar til at barnehagen fremmer undring over likheter og forskjeller, solidaritet og respekt for menneskeverd og mangfold og på den måten bidrar til en danningsprosess mot å se seg selv i en større sammenheng (Kunnskapsdepartementet, 2017).

I dokumentene for prosjektet kan vi lese at prosjektets slagord er «jeg kan", og slagordet er hentet fra arbeidet til Mamma Maggies arbeid med å dyktiggjøre barna til å mestre livet der de er (Skeie, 2014). Gjennom disse ordene ønsker barnehagen å flytte fokus fra et ensidig orientalistisk preg over til et mestringsorientert fokus der «barn kan» (barnehagens plandokument). Fokuset på barnets potensial og mestringsevne løftes frem ved at informasjonen om prosjektet i filmene og bildene gir et bilde av barn som mestrer elementer av sine liv som norske barn kan kjenne seg igjen i. De fremstilles som barn som lever under andre vilkår, men som like fullt er ukrenkelig verdifulle med rettigheter til utdanning, mat og trygghet. Dette er viktige kjernepunkter ved globalt medborgerskap: «The focus becomes one's connection to others, with the ultimate goal of developing an understanding that each of us is a complex, fully realized, and highly valuable individual» (Hancock, 2017, s. 572).

\section{Kontinuitet er betydningsfullt for holdningsdanning}

Solidariske holdninger og handlinger må være en del av barnas sosialisering og realiseres i danningsmiljøet (Thoresen \& Winje, 2017, s. 89). Holdninger er knyttet til våre verdier, og de er ofte knyttet til hvordan vi er primærsosialisert (Bergersen, 2017, s. 21). Det er derfor av stor betydning at barnehagen etablerer arbeider med verdier selv med de minste barna og at foresatte invol- 
veres. En bevisstgjøring mot det globale perspektivet vil være viktig for å rotfeste dette tidlig. For å bidra til danningen mot det globale er det altså viktig at det globale perspektivet er til stede på et tidlig stadium. Holdninger utgjør et grunnlag for hvordan vi handler, og holdninger er relativt varige sammenliknet med meninger som endrer seg oftere (Lund, 2013). Endringer av holdninger kan være et omfattende arbeid da det både handler om å bli bevisst sine egne holdninger og systematisk velge inn kunnskap og følelser som fører til en holdningsendring (Bergersen, 2017, s. 20). Ledelsen i barnehagen har et ansvar for å prioritere holdningsarbeid som omhandler verdier som likeverd og «mangfold som ressurs» blant personalet, foresatte og barn (Spernes \& Hatlem, 2019, s. 214). Mangfold skal skriftliggjøres i barnehagens planer som virksomhetsplan, årsplan og planer for avdelinger (Spernes \& Hatlem, 2019, s. 219).

Flere av de foresatte forteller at barnehagen har bidratt til å formidle viktige holdninger gjennom prosjektet som de ser igjen etter hvert som barna blir eldre. En av de foresatte er tydelig på dette når han sier: «Jeg tenker jo det at det har vært det samme prosjektet over år danner et grunnlag der de lærer mer og de skjønner det mer [...] Når de er 3 år så forstår de det på en måte og når de er 4 år på en annen og når de er førskolebarn på en annen måte». Denne foresatte uttrykker også at prosjektet har konsekvenser utover barnehagetiden når han sier "[...] jeg tror det sitter dypt i dem når de blir sikkert både 8, 9, 10 fordi det er plantet såpass tidlig» (foresatt 2 dag 1).

For å tilpasse informasjonen til aldersgruppene har barnehagen utarbeidet et pedagogisk plandokument. I dette beskrives blant annet alderstilpassede filosofiske samtaler mellom barn og ansatte om begreper som rettferdighet og likeverd. Barna øves i å tenke igjennom likheter og forskjeller, og en mer rettferdig fordeling av ressurser i lokalmiljøet, men også globalt. Disse øvelsene er viktige bidrag til å styrke kontinuiteten i danningsarbeidet. Det hjelper barna med å sette ord på tanker rundt sin egen forståelse av den nære og den vide konteksten de er en del av. Videre i det pedagogiske arbeidet brukes materiale som «vennebøker» som er basert på FN’s Barnekonvensjon (Regjeringen, 2003). Et didaktisk grep er at barna lager egenprodusert kunst med utgangspunkt i resirkulert materiale, slik som barna på søppelhaugene. Ved å lage og selge produktene på aksjonsdagen 24. oktober, gis barna en reell mulighet til medvirkning. 
I barnehagens arbeid med prosjektet har kunnskapsformidlingen blitt tilpasset de ulike aldersgruppene etter hvert som de får mer erfaring med prosjektet. Barnehagen har på den måten måttet tilpasse sentrale deler av innholdet i prosjektet til de ulike aldersgruppene og tatt hensyn til forkunnskapen hos barna. Dette har vært viktig slik at prosjektet kan skape engasjement over tid og møte barnas nysgjerrighet og på den måten bidra til nye steg i danningsprosessen. Rammeplanen for barnehagen (Kunnskapsdepartementet, 2017) sier at «Barnas nysgjerrighet, kreativitet og vitebegjær skal anerkjennes, stimuleres og legges til grunn for deres læringsprosesser. Barna skal få undersøke, oppdage og forstå sammenhenger, utvide perspektiver og få ny innsikt». Barnehagen skal videre sørge for progresjon og utvikling av innhold og støtte barnas refleksjoner rundt fenomener og tema. Denne måten å forstå læring på, har likhetstrekk med det aktualiserte dybdelæringsbegrepet i grunnskolen. Dybdelæring beskrives som en prosess der man reflekterer over egen læring og oppøver evnen til kritisk tenkning slik at man kan etablere gode holdninger og foreta etiske vurderinger (Utdanningsdirektoratet, 2019). På denne måten kan vi si at arbeidet med prosjektet på den ene siden er en begynnende øvelse i skolens fremtidsrettede arbeidsmetode og på den andre siden styrker kontinuiteten i danningsarbeidet.

Det er imidlertid viktig å ha et kritisk blikk på barnas forståelse av prosjektet da det kan være utfordrende å skille mellom hva som er barnas egne refleksjoner og de foresattes tolkning av barnas utsagn: « [...] vi leser våre egne voksne forståelser inn i barna, det er vi voksne som føler at barna i Egypt er urettferdig behandlet. Jeg tror ikke det har skapt et veldig sterkt engasjement for barn i andre land, det er et altfor stort ansvar til å ligge på en 5åring» (foresatt 3, dag 1). Utsagnet viser at det er ulike tolkninger av barnas forståelse av prosjektet. Dette kan både forklares ved at barna forstår prosjektet på ulikt nivå, eller ved at de foresatte har ulik oppfatning av innholdet i barnas utsagn.

\section{A tenke globalt og lokalt; à sette ting i perspektiv}

Børhaug og Bakken (2009, s. 16) skriver: «Solidaritetsprosjekter i skole og barnehage er mulige bidrag til danning for en globalisert verden». Videre skriver de: 
Denne typen tiltak i skole og barnehage er viktige fordi de kan være bidrag til en danningsprosess som forbereder barn og unge til en verden der politiske, kulturelle og økonomiske globaliseringsprosesser knytter områder og grupper nærmere sammen i kompleks, gjensidig avhengighet. (2009, s. 16).

Likevel stiller Børhaug og Bakken (2009) kritiske spørsmål til solidaritetsarbeid og hevder at flere av prosjektene som barnehager engasjerer seg i er preget av orientalisme der «mennesker i andre land gjøres til passive offer som bare kan hjelpes ved vår hjelp. Handlingsrom og muligheter i den lokale konteksten oversees» (Bakken og Børhaug 2009, s. 22). En av informantene peker på dette: «Det slår meg at det er et typisk prosjekt som er veldig langt unna geografisk, det er så langt unna og så eksotisk at det blir en spennende fortelling fra der nede» (foresatt 3, dag 1). Informanten sier videre:

Kanskje det kan være med på å skape en distanse til at solidaritet er å gi vekk veldig abstrakte penger til et helt annet sted [...] det blir så fort den fortellingen at vi har det så bra og alle de andre har det så fryktelig vanskelig, så blir det en sånn ubalanse som er med på å opprettholde en sånn fortelling om Norge som det fantastiske landet og hele resten av verden som kjørt som det er. (foresatt 3, dag 1).

Sitatene bekrefter en etnosentrisk forståelse av solidaritetsarbeid der vår virkelighet og levestil er målet å strekke seg mot (Spernes og Hatlem, 2019). Dette står i motsetning til funn i barnehagens planer der fokuset skulle være på lokalkunnskap og Mamma Maggie som forvalter av lokalt initiativ for å skape endring. Barnehagens fokus på lokalkunnskap kan balanseres mot et typisk orientalistisk prosjekt der vesten og de andre står som dikotomiske størrelser. I orientalismebegrepet ligger det at vesten har kunnskaper og evner til å bedre livet for de de andre, og «de andre» forstås som en type «orientaler» som er mottakere av bistanden (Bakken og Børhaug, 2009).

I solidaritetsprosjekter må de ansatte være seg bevisst hvilke holdninger de har slik at prosjektene ikke får et entydig etnosentrisk preg der de fremstilles som stakkarslige eller eksotiske (Spernes \& Hatlem, 2019, s. 238). Begrepet etnosentrisme forklares ved at man bruker sin egen kultur som målestokk for rett og galt, godt og ondt. Andre kulturer forstås gjennom ens egen kulturs briller og vurderes som dårligere, mindreverdige eller lenger bak 
i utviklingen enn ens egen kultur. På den annen side finner man begrepet kulturrelativisme der man tenker at man ikke kan vurdere hva som er rett og galt og godt og ondt gjennom sin egen kulturs målestokk (Eriksen, 2002). For å unngå at solidaritetsprosjekter preges av slike dikotomiske holdninger, må de ansatte ha kunnskap om solidaritetsarbeid og menneskerettigheter (Spernes \& Hatlem, 2019, s. 238) og knytte prosjektet til de verdiene som globalt medborgerskap kommuniserer Dette er for eksempel respekt, likeverd og barns rettigheter. Sageidet utdyper det som foresatt 3, dag 1 peker på gjennom å hevde at forskjellen på generelle prinsipper knyttet til bærekraftig utvikling og gjennomføring i praksis gjelder det norske samfunnet spesielt da Norge tar en rolle som frontløper, og at «til en viss grad får vi et lignende inntrykk når det gjelder norske barnehager» (Sageidet, 2015, s. 111).

Eva Johansson (2009) peker i artikkelen «The preschool child of today - the worldcitizen of tomorrow» på behovet for at barnehagen bidrar til at bærekraftig utvikling er et moralsk anliggende der barn må lære å se sammenhengen mellom å være lokale innbyggere i eget land og samtidig en del av verden som en helhet. "We are as humans, part of, and responsible for, a common world» (Johansson, 2009, s. 81). Her peker Johansson på at denne todelte utviklingen som utfordres av den postmoderne individualitetstanken, blant annet ved Baumann, er en utvikling som preger stadig flere land: «This picture of increasing individuality has been described as a worldwide process characterising post modern societies» (Johansson 2009, s. 81). Denne tanken kan også utfordres av det økende fokuset på nasjonalisme som vi ser spor av i Europa gjennom politiske endringer.

På nasjonalt nivå legges det politiske føringer for at barn skal få muligheten til å rette blikket mot utfordringer i vår felles verden (Kunnskapsdepartementet, 2017). Likevel kan man stille spørsmål, slik som foresatt 3 dag 1 gjør, ved om det er mulig å gi barn et globalt perspektiv i barnehagealder? Vi kan nærme oss problematikken ved å presentere fortellinger fra en verden utenfor barnehagen og utenfor Norge, og samtidig knytte det til relevante erfaringer fra barnas liv.

Globalt medborgerskap gir assosiasjoner til noe felles som består av ulike perspektiver der mennesker skiller seg fra hverandre og er like hverandre på flere vis uavhengig av nasjonalitet. En slik tilnærming finner vi også hos Hancock (2017) som sier: «Global citizenship education takes the work of mul- 
ticultural education one step further. Like multiculturalism, global citizenship actively works to build an environment where multiple perspectives are incorporated into curricula» (Hancock, 2017, s. 572). Flere av informantene påpeker at solidaritetsprosjektet bidrar til å sette ulike tema og problemstillinger i perspektiv, eksempelvis hva som er rettferdig og urettferdig, og forteller at det har hatt en verdi for familien. En av informantene beskriver det som en øvelse i filosofiske samtaler; å se noe i et større perspektiv. Foresatt 5, dag 1 sier:

Vi har jo hatt noen sånne samtaler rundt middagsbordet [...] når ungene sier «det der er så utrolig urettferdig» så har jeg spurt dem «er det egentlig så urettferdig?» Da har de sagt at det kanskje ikke er så urettferdig at jeg ikke fikk den leken nå, men det er urettferdig det som Stefanusbarna opplever. Så har vi av og til tatt de med inn i sånne perspektiver. Hva er det egentlig som er urettferdig?

Flere av de foresatte i det første gruppeintervjuet trekker frem perspektivtaking som en gevinst av solidaritetsprosjektet. I en filosofisk samtale er nettopp dette ett av formålene, Børresen \& Persson (2018, s. 250) skriver: «Man skal bli utfordret og teste egne ideer opp mot andres innvendinger gjennom å prøve ut tanker, måtte forklare og begrunne og i noen tilfeller oppgi sitt standpunkt.» $\AA$ se saker fra ulike perspektiver, er ett av kjennetegnene ved filosofiske samtaler der man drøfter ulike dilemmaer, og disse øvelsene kan bidra til at rammeplanens fagområde «etikk, religion og filosofi» realiseres i barnehagen (Thoresen \& Winje, 2017). Samtalene i barnehagen har preg av filosofiske samtaler selv om de ikke oppfyller alle krav til struktur. Likevel inneholder de flere karakteristiske trekk, som å tenke filosofisk, å lytte til andre, å se forbindelser og likheter, å lage hypoteser og utøve god dømmekraft (Bjørndal, 2019). Intensjonene med de filosofiske samtalene er blant annet at samtalene skal bli en del av barnas liv, og funnene viser at barna tar med seg samtalene utenfor barnehagen. Samtaler om eksistensielle spørsmål trekkes frem i rammeplanen for barnehagen som en viktig del av barnehagens dialogiske virksomhet, vi kan lese følgende i kapittelet om etikk, religion og filosofi (Kunnskapsdepartementet, 2017): «Gjennom å samtale om og undre seg over eksistensielle, etiske og filosofiske spørsmål skal barn få anledning til selv å formulere spørsmål, lytte til andre, reflektere og finne 
svar.» På denne måten kan barnehagen legge et grunnlag for kritisk tenkning og dømmekraft. Den etiske dømmekraften oppøves hos barna i perspektivtaking mellom rettferdig og urettferdig, og nok og for lite, i samtale med foresatte og ansatte i barnehagen. Filosofiske samtaler med barn har som formål å utforske fenomener og undre seg over det man tar for gitt. Samtalene kan utforske ulike perspektiver og kan være av stor betydning for barnas dannelsesprosess (Olsholt \& Schelderup, 2018, s. 78).

Man kan imidlertid stille seg spørrende til om barn har evnen til å tenke filosofisk igjennom konkrete fenomener og abstrakte problemstillinger. Olsholt og Schelderup (2018, s. 78) hevder at tenkning er en primærferdighet, og at barn kan filosofere og tenke kritisk, dog ikke i samme grad som voksne. A tenke kritisk er en evne som utvikles fra barndommen og gjennom livsløpet (Bjørndal, 2019). Å tenke filosofisk, eller å tenke kritisk, er en ferdighet som kan oppøves, og det gir barna øvelse i å forstå likheter og forskjeller, se sammenhenger og på den måten bidra til barns danning mot globalt medborgerskap.

\section{Konklusjon}

I denne studien har vi undersøkt foresattes refleksjoner rundt barn og voksnes erfaringer med solidaritetsarbeid i barnehagen i lys av problemstillingen: «Hvordan bidrar barnehagens solidaritetsarbeid til at barn dannes til globalt medborgerskap?»

Basert på våre funn ser vi for det første at det er av betydning å ha en rollefigur (her Mamma Maggie) som barna identifiserer prosjektets verdier med. For det andre er langsiktigheten og kontinuitet i prosjektet viktig for å arbeide med holdninger hos barn og foresatte. Det tredje funnet viser at prosjektet egner seg godt som utgangspunkt for filosofiske samtaler der perspektivtaking står sentralt. Dette kan være viktig for å øve seg i sentrale sider i globalt medborgerskap. Det er imidlertid nødvendig at barnehageansatte er seg bevisst mulige fallgruver i dette arbeidet når det gjelder oppfatningen av «oss» og «de andre». Vi konkluderer med at slike prosjekter er viktige for barnehagen som danningsarena for å øke bevisstheten rundt globalt medborgerskap. 


\section{Referanser}

Barnehageloven (2005, juli 3). Lov om barnehager. Hentet fra www.lovdata.no: https://lovdata.no/dokument/NL/lov/2005-06-1764?q=lov\%20om\%20barnehager

Bergersen, A. (2017). Global forståelse. Barnehagen som kulturell brobygger. Bergen: Fagbokforlaget.

Bjørndal, K.E.W. (2019). Barns utvikling av kritisk tenkning - avgjørende for bærekraftig utvikling. I: V. Bergan \& K.E.W. Bjørndal (red.), Berekraft i praksis i barnehagen. (2. utg. s. 85-98). Oslo: Universitetsforlaget.

Bryman, A. (2016). Social Research Methods (5th ed.). London: Oxford University Press.

Børhaug, K. \& Bakken, Y. (2009). Internasjonal solidaritet i barnehage og på barnetrinnet. Norsk pedagogisk tidsskrift 1(93), 16-27.

https://www.idunn.no/npt/2009/01/internasjonal_solidaritet_i_barnehage_og_pa_barnetrinnet

Børresen, B., Persson, V. (2018). Filosofisk samtale i undervisningen. Norsk pedagogisk tidsskrift. 03 /2018 (102), 247-258. DOI: https://doi.org/ 10.18261/issn.1504-2987-2018-03-04

Creswell, J.W. (2013). Qualitative inquiry and research design. Thousand Oaks, USA: SAGE publications.

Dalland, O. (2012). Metode og oppgaveskriving (5. utg.). Oslo: Gyldendal akademisk.

Eriksen, T.H. (2002). Flerkulturell forståelse. Oslo: Universitetsforlaget.

FN-Sambandet (2019). Barekraftig utvikling. Hentet fra: https:/www.fn.no/ Tema/Fattigdom/Baerekraftig-utvikling

Hancock, R.E. (2017). Global Citizenship Education. Journal of Research in Childhood Education 31(4):571-580.

Doi: 10.1080/02568543.2017.1346731

Johansson, E. (2009). The preeschool child of today - the worldcitizen of tomorrow. International Journal of Early Childhood 41(2):79-95. DOI: 10.1007/BF03168880

Kemp, P. (2005). Verdensborgeren som padagogisk ideal. Pædagogisk filosofi for det 21. århundrede. København: Reizel. 
Krumsvik, R.J. (2019). Kvalitativ metode i lererutdanninga. Bergen: Fagbokforlaget.

Lund, I. (2013). Et etisk skråblikk inn i barnehagen når relasjoner utfordrer. Forebygging.no. Hentet fra: http://www.forebygging.no/Artikler/20142012/Et-etisk-skrablikk-inn-i-barnehagen-nar-relasjoner-utfordrer/

Olsholt, Ø. \& Schelderup, A. (2018). Filosofi og etikk i barnehagen. Oslo: Cappelen Damm akademisk.

Regjeringen (2003) FNs konvensjon om barnets rettigheter. Hentet fra https://www.regjeringen.no/globalassets/upload/kilde/bfd/bro/2004/000 4/ddd/pdfv/178931-fns_barnekonvensjon.pdf

Sageidet, B.M. (2015). Bærekraftig utvikling i barnehagen - bakgrunn og perspektiver. Norsk Pedagogisk tidsskrift 99(02):110-123. https:/www.idunn.no/ npt/2015/02/baerekraftig_utvikling_i_barnehagen_-_bakgrunn_og_perspektiv

Skeie, E. (2014). Mamma Maggie - en fortelling fra Egypt. Oslo: Luther.

Spernes, K. \& Hatlem, M. (2019). Den flerkulturelle barnehagen i bevegelse.

Teoretiske og praktiske øvelser. Oslo: Gyldendal akademisk.

The Citizen. (2020, 17. mars). The 2020 Nobel Peace Prize: Who Will Win?

Hentet fra https://www.thecitizen.co.tz/tanzania/news/business/the2020-nobel-peace-prize-who-will-win-2705716

Thoresen, I.T. \& Winje, G. (2017). Religioner, mangfold og etikk i barnehagen. Oslo: Cappelen Damm.

UNESCO. (2015). Incheon Declaration and Framework for Action for the implementation of Sustainable Development Goal 4. Hentet fra: http://uis.unesco.org/sites/default/files/documents/education-2030incheon-framework-for-action-implementation-of-sdg4-2016-en_2.pdf

UNESCO. (2019). Global Education Monitoring Report 2019: Migration, Displacement and Education - Building Bridges, not Walls. Paris: UNESCO Publishing. Hentet fra: https://unesdoc.unesco.org/ark:/ 48223/pf0000265866

Kunnskapsdepartementet. (2017). Rammeplan for barnehagen. Forskrift om rammeplan for barnehagens innhold og oppgaver. Hentet fra https://www.udir.no

Utdanningsdirektoratet. (2019). Dybdelaring. Hentet fra: https://www.udir.no/ laring-og-trivsel/dybdelaring/ 